УДК $82-1 ; 821.581 ; 811.581$

DOI 10.25205/1818-7919-2020-19-10-100-116

\title{
Performative Strategies \\ in Contemporary Chinese Avant-garde Poetry
}

\author{
Yu. A. Dreyzis \\ Moscow State University \\ Moscow, Russian Federation
}

Abstract

The paper presents an attempt to explore the problem of mediality in Chinese poetry of the last thirty years. New Chinese poetry is particularly susceptible to the influence of the latest concepts of modern art and now more than ever needs a clear contextualization in relation to other forms of culture and avant-garde practice. This can be achieved through applying an analysis paradigm for performative word art developed by Dr. Tomáš Glanc in the context of Czech and Russian neo-avant-garde. It perceives experimental poetry as a form that fulfills a shift of the word thus making it labile. Examples of this phenomena can be found in Chinese poetry in the works of Ouyang Jianghe, Yang Xiaobin, Ouyang $\mathrm{Yu}, \mathrm{Xia} \mathrm{Yu}$, Chen Li, Xu Bing, Wuqing and many more experimental artists. Their creative use of word shift principles shows how performative strategies are adapted in contemporary Chinese poetry keeping in mind the specific hanzi (character) medium that it is based upon. It seems both a continuation of a long-existing tradition and a radical exploration of the 'iconic turn' in the field of language.

Keywords

Chen Li, contemporary China, experimental poetry, internet poetry, language shift, Ouyang Jianghe, Ouyang Yu, PRC poetry, Taiwan poetry, text linguistics, web poetry, Wuqing, Xia Yu, Xu Bing, Yang Lian, Yang Xiaobin

Acknowledgements

The research was carried out with the financial support of the Russian Science Foundation (project no. 19-18-00429 "Language mechanisms of accommodation of cultural systems in various types of discourse of the $20^{\text {th }}$ and $21^{\text {st }}$ centuries") at the Institute of Linguistics of the Russian Academy of Sciences

For citation

Dreyzis Yu. A. Performative Strategies in Contemporary Chinese Avant-garde Poetry. Vestnik NSU. Series: History and Philology, 2020, vol. 19, no. 10: Oriental Studies, p. 100-116. (in Russ.) DOI 10.25205/1818-7919-2020-19-10100-116

\section{Перформативные стратегии в современной китайской авангардной поэзии}

\section{Ю. А. Дрейзис}

Московский государственный университет

им. М. В. Ломоносова

Москва, Россия

\section{Аннотаиия}

В статье представлена попытка исследовать проблему медиальности в китайской авангардной поэзии последних тридцати лет. Поэтический текст сегодня, в эпоху междисциплинарных связей, претерпевает значительные изменения: авангардные поэтические формы, такие как визуальная, звуковая, перформативная поэзия, напрямую задействуют опыт смежных видов искусства, создавая принципиально новый художественный продукт. В то же время стихотворение сходится непосредственно с другими форматами и может неявно заимст- 
вовать их технику и оптические эффекты - подчёркивая сложные паттерны визуального устройства или применяя некоторые особенности музыкальной формы. Новая китайская поэзия особенно восприимчива к влиянию новейших концепций современного искусства и теперь как никогда нуждается в четкой контекстуализации в отношении других форм культуры и авангардной практики. Поставленная цель достигается путем применения парадигмы анализа для перформативного изобразительного искусства, разработанной Томашем Гланцем в контексте чешского и русского неоавангарда. Концепция Гланца анализирует экспериментальную поэзию как форму, которая каким-то образом работает со сдвигом слова - как материальной единицы и как единицы, которая воспринимается само собой разумеющейся в рамках линейной последовательности текста. Это позволяет исчислить характерные стратегии такой поэзии: её работу с пространственными измерениями текста, выстраивание новых отношений между словом и изображением, исследование телесности текста и его эзотерического измерения, трансгрессию, двойное / тройное кодирование. Примеры такого типа медиальности в поэзии Большого Китая можно найти в работах Оуян Цзянхэ, Ян Сяобиня, Оуян Юя, Ся Юй, Чэнь Ли, Сюй Бина, Уцина и многих других экспериментальных авторов. Их творческое использование принципов языкового сдвига показывает, как перформативные стратегии адаптируются в современной китайской поэзии. Их адаптация выглядит одновременно продолжением традиции и радикальным применением «иконического поворота» в области языка.

Ключевые слова

интернет-поэзия, китайская поэзия, лингвистика текста, Оуян Цзянхэ, Оуян Юй, современный Китай, Сюй Бин, Ся Юй, тайваньская поэзия, Уцин, Чэнь Ли, экспериментальная поэзия, языковой сдвиг, Ян Лянь, Ян Сяобинь

Благодарности

Исследование выполнено при финансовой поддержке РНФ в рамках научного проекта № 19-18-00429 «Языковые механизмы аккомодации культурных систем в различных видах дискурса XX и XXI вв.» в Институте языкознания РАН

Для ицитирования

Дрейзис Ю. А. Перформативные стратегии в современной китайской авангардной поэзии // Вестник НГУ. Серия: История, филология. 2020. Т. 19, № 10: Востоковедение. С. 100-116. (на англ. яз.) DOI 10.25205/18187919-2020-19-10-100-116

\section{Introduction}

This paper is an attempt to explore the problem of mediality in Chinese poetry of the last thirty years. Poetic text as we know it, in our era of interdisciplinary connections, seems to be rapidly becoming obsolete. Avant-garde poetic forms, such as visual, sound, performative poetry, directly involve the experience of related art forms, creating a fundamentally new artistic production. At the same time, the poetic text itself, the one we are accustomed to perceiving, undergoes significant changes. The poem can converge directly with other formats and can implicitly borrow their technique and optical effects by emphasizing complex patterns of visual setup or applying some features of the musical form.

Chinese poetry is particularly susceptible to the influence of the latest concepts of contemporary art since the early 1990s. Now more than ever it needs a clear contextualization in relation to other forms of culture and avant-garde practice. One of the possible contextualizations is based on applying an analysis paradigm for performative word art as developed by Dr. Tomáš Glanc in the context of Czech and Russian neo-avant-garde ${ }^{1}$.

\footnotetext{
${ }^{1}$ A detailed presentation of this paradigm took place in the Centre for Linguistic Research of World Poetry (Institute of Linguistics, Russian Academy of Sciences) in November 2015 and the video version of the presentation can be viewed online on the Centre's website (in Russian): Glanc T. Video of Tomáš Glanc's report "Performative poetry and its conditionality" // Institute of Linguistics RAS. 7 November 2015. URL: http://iling-ran.ru/main/news/151110_plr_video (accessed 15.02.2016).

The term neo-avant-garde refers to the second wave of the avant-garde, which may be defined in a number of different ways: as a rehashing of the first avant-garde, as a maturation, or as something entirely distinct from the earlier movement [Šuvaković, 2003. P. 26]. The neo-avant-garde is often considered to be a critical practice on the fringes of mainstream modernist culture, thus reminiscent of the experimental word art practiced by avant-garde poets of China. In the context of contemporary Chinese poetry, the term 'avant-garde' (xianfeng 先锋) converges with the 'unofficial' (feiguanfang 非官方) within the framework of the general institutional and aesthetic dichotomy as shown by Magiel van Crevel [van Crevel, 2008. P. 5-12]. This avant-garde poetry from China is distinct from the orthodox or official (guanfang 官方) poetry that reflects state-sanctioned views of literature and art. The distinction of avant-garde and orthodoxy remains meaningful,
} 
At the centre of Glanc's conception lies the idea that the main feature of the performative avantgarde poetry is the way it deals with the mediality ${ }^{2}$ of the poetic word. This type of poetry is a practice that somehow involves the shift of the word - as a material unit and as a unit, which is taken for granted within the framework of the linear sequence of the text, thereby creating the phenomenon of the labile word. The word starts vibrating in its elementary presence as part of the textual sequence.

Starting from this thesis, Glanc offers a set of characteristics of the experimental verse related to its special properties that involve the shift of the word. The practice of performative poetry is closely linked with samizdat activities across the Eastern Bloc, in which individuals reproduced underground publications by hand and passed the documents from reader to reader. Vladimir Bukovsky summarized this grassroots practice as follows: "I write it myself, edit it myself, censor it myself, publish it myself, distribute it myself, and spend jail time for it myself" [Bukovsky, 1979. P. 141]. It created a mediality zone involving the physiological component that emphasized the connection between the word/letter and the paper or other types of carriers as a physically concrete plane and the one who produces the text as a guarantor of the labile connection.

This spatial dimension of the text is present in visual poetry at least since ancient times ${ }^{3}$, but in contemporary poetry apart from being a continuation of the line that lasts for many centuries it comprises different attempts to save the word in the situation in which it appears in our hypertext, digital culture. The relationship between the text and the subject exist on the verge between literature and the material world/visual art. As Winfried Nöth puts it, the text manifests itself within the three dimensions reflecting the main dimensions of human orientation: the horizontal (right/left), the vertical (above/below), and the sagittal (front/back) [Nöth, 1996. P. 604]. In performative poetry, the horizontal dimension is actualized through the subversive practices that involve the linearity of the text, while the sagittal dimension becomes extremely important for its interaction with the me-

even though the boundaries between them have grown fuzzy over the years. What is even more important, Chinese avantgarde (also in Taiwan and Hong Kong) opposes the mainstream - converging with the neo-avant-gardist practices of Europe. Since the mid-1980s the term 'avant-garde' has been borrowed from western literary theory to refer to works of art that push out the edges of accepted artistic practice, in other words in reference to experimental forms and techniques [Yeh, 1991].

${ }^{2}$ The concept of the medial (Germ. Medialität) is actively apllied in linguistics, in modern theories of text, and in the theory of communication. It serves to denote a form, a way of transmitting information, a communicative channel. Interaction of various communication channels is reflected in several correlated terms. In English-language publications, these are multimodality, bimodality, German-speaking researchers operate, along with the above-mentioned mediality, with the term multimediality (Multimedialität), as well as polymediality, polycode.

Mediality correlates with the concept of a communicative code, if we understand a code as a system of conventions, symbols, signs, rules combined with each other for transmitting, processing, memorizing and storing information in the most optimal form. Both of these understandings of the medial - as a communicative channel and as a communicative code - do not contradict, but rather complement each other. Thus, mediality is not limited to communication with a technical carrier of information and with technogenic processes in modern communication. At the same time, mediality in this sense is not synonymous with media or media discourse. It makes sense to understant the medial as a special format for transmitting information. Mediality is the shaping of meaning, the attachment of meaning to a certain format, a way of expression [Chernyavskaya, 2015]. The "medial turn" in linguistics is a new medial paradigm which underlines a new type of subject and can be stated as a correlation between cognition and its medium, material form.

${ }^{3}$ It is believed that visual poetry began back in ancient Greece, around the 3rd century BCE - with Simmias of Rhodes, Dosiad, Theocritus, Aratus [Grauz, 2019. P. 39].

In China, the unity of the image and the integrity of communicative space was firstly explored through calligraphy. Later the Taoists created a special written culture of "heavenly", or "cloudy" (sacred) writings emanating magical powers. These cursive signs-talismans combined graphics and drawing and were a clear example of the continuity of nature and spirit, images and extra-figurative. Instead of the European parallelism of the "internal" and the "external", expressed in objective images, the Chinese form of writing asserts the correlation of incommensurable quantities, like the relationship of body and trace, sound and echo. This created a kind of meta-space - a symbolic space that realizes the unity of the "disconnected" world.

The methods of visualizing a poetic text were not only graphic, but also included combinations with three-dimensional man-made and natural (stone) objects and even with dance performances (construction of dancers in the form of characters that form a text), etc. 
dium involved (the opposition of the foreground and background somehow enters the semantics of the text).

This correlates with the idea of the 'iconic turn' that occurred in philosophy and social sciences in the 1990s. This idea was suggested by the Swiss art critic Gottfried Boehm and was associated with the recognition of the semantic autonomy of the image [Boehm and Mitchell, 2009]. For performative poetry, the iconic turn suggests that the text becomes actively involved in the process of its perception: the text appeals to the reader in a way that violates its usual existence. Not only do we perceive the text and consume it, but also the text actively looks at us revealing its plasticity. The intervention strategy in use is based on the principle that violates the status quo of the linear text. The spatial organization of the text per se in avant-garde poetry is an intervention in the field of text logic.

Today's avant-garde poet in China has access to the Internet and many more small - and laxly controlled - publishing houses than the poet of the 1980s [Day, 2005. P. 11], which changes modes of operating with the text. To date the most comprehensive English-language study of developments after - and because of the influence of the early 1980s avant-garde - can be found in Maghiel van Crevel's Language Shattered: Contemporary Chinese Poetry and Duoduo (1996). Modern Chinese Poetry: Theory and Practice since 1917 by Michelle Yeh (1991) is the best overview in English of the overall aesthetic development of twentieth century Chinese poetry to date, but it deals only briefly with the poetry of the 1980s. More information on contemporary poetry after the 1980s in Greater China ${ }^{4}$ can be found in van Crevel's Chinese Poetry in Times of Mind, Mayhem and Money (2008) and in the volume New Perspectives on Contemporary Chinese Poetry edited by Christopher Lupke, but none of them explores the phenomenon from the performative perspective. Other aspects of contemporary poetic practice in China that are closely connected with the performativity of the text have been explored in Modern Poetry in China: A Visual-Verbal Dynamic by Paul Manfredi (2014) and Verse Going Viral: China's New Media Scenes by Heather Inwood (2014).

This paper contributes to the current state of research in Chinese avant-garde poetry by applying the performative perspective as developed by Glanc that is deeply rooted in the linguistic approach, where the concept of the performative receives an expansive interpretation, levelling the difference between a communicative act and a social action. Its various implications are explored through the prism of Chinese avant-garde/unofficial poetry (and not necessarily only the works in the purely visual or concrete verse format) produced both in Greater China and beyond, in diasporas, which allows this poetry production to be included in the global context of the experimental art of the 20th and 21 st centuries. This thesis will aim to illustrate this with several examples from the texts of poets who adhere to aesthetically different reference points (including the authors of both the popular/minjian 民间 and the intellectual/zhishifenzi 知识分子 camps) ${ }^{5}$. These pieces of word art are being considered and studied under the same category because contemporary 'intellectual' and minjian poets share a vision of the poetic as a 'sublimation' of the ordinary. In practice, they are increasingly aware that poetic language is itself a kind of deviation; it is a parade of abnormalities, even as it aspires to let the ordinary rule.

Just as his ancestor was convinced of the idealness of literature as a medium, the contemporary Chinese poet views poetic language as the ultimate form of language. Therein lies the paradox of

\footnotetext{
${ }^{4}$ The term “Greater China” (Da Zhonghua 大中华) here covers all territories controlled by the PRC (Mainland China, including Hong Kong and Macao) and territories controlled by the Republic of China (Taiwan and some neighboring islands). This also includes Singapore due to its sizeable Chinese community: $74.3 \%$ of Singapore's population is Chinese, see Singstat. Population trend. Department of Statistics Singapore, 2017, https://web.archive.org/web/20171107010632/ж; http://www.singstat.gov.sg/docs/default-source/default-document-library/publications/publications_and_papers/ population_and_population_structure/population2017.pdf, retrieved 09/10/2019. An estimated 6.69 million Chinese live in Malaysia, also sometimes included in the term, see Department of Statistics, Malaysia. Current Population Estimates, Malaysia, 2017-2018, 2018, https://www.dosm.gov.my/v1/index.php?r=column/pdfPrev\&id=c1pqTnFjb29HSnNYNU piTmNWZHArdz09, accessed 10.09.2019.

${ }^{5}$ Both present two poles in the polemics about the language of contemporary Chinese poetry. For more information see [Li, 2008. P. 185-201].
} 
contemporary Chinese verse: Chinese authors see themselves both as continuators of Chinese aesthetical and philosophical traditions as well as heirs of Western philosophy and Western modernism's linguistic experimentation. They borrow traditional techniques such as parallelism, elliptical constructions, and nontrivial semantic links created through language phonographics to create connections with classical images and the tradition of 20th century Chinese 'New Poetry'. Experiments of this sort expand the capabilities of language and construct a type of text that relies on unconventional usage supported by mechanisms for ensuring the semantic cohesion of the text; it explores language boundaries and opens Chinese poetry to the world.

\section{Mediality: Subversion and Texturizing}

Firstly, the idea of a subversive appellation to those moments of the text that codify it in language turns out to be extremely important for avant-garde poetry in China and beyond. The word seems to come out of its position under the influence of some kind of subversive mechanism. This technique plays a very important role in the work of one of the main pillars of 'intellectual' poetry Ouyang Jianghe 欧阳江河 (b. 1956) ${ }^{6}$. Already in his early poem Handgun (Shouqiang 手枪, 1988), the author breaks the words into their constituents, likening his experiment to the traditional fortune-telling practice of chaizifa 拆字法: in the text of the poem, the banal word 'gun' recovers its internal form and turns into "hand + gun" ${ }^{7}$. In the collection Doubled Shadows (2012), translated by Austin Woerner, the poem appears three times: first in two separate free versions subtitled 'after Ouyang Jianghe', and once in an appendix that gives a more literal, annotated translation:

a handgun can be taken apart

into two unrelated things

a hand and a gun

a gun lengthened becomes a Party

(党 dang = any faction or political party)

a hand painted black becomes another Party

and things themselves can be further disassembled

(东西 dongxi = thing, object; the characters 东 dong and 西 xi mean east and west, respectively) into pairs of opposing dimensions

the world divides in infinite character-parsings

(拆字法 chaizifa $=$ the practice of parsing Chinese words into separate characters or characters

into separate components, traditionally for the purposes of fortune-telling)

with one eye we look for love

the other we ram down the barrel

the bullets ogle

our noses aim at enemies' parlors

politics tilt leftward

a man shoots in the east

in the west, a man falls

\footnotetext{
${ }^{6}$ Ouyang Jianghe is a poet, calligrapher, musical critic, a native of Sichuan. He currently lives in Beijing, but also maintains close relations with the Western art circles, primarily in the United States, where he is a frequent visitor.

${ }^{7}$ In addition to the relatively transparent case of 'breaking' the 'handgun', there are several more complex cases in the text, see Admussen N. Disassembling the Handgun // Boston Review. 15 December 2014. URL: http://bostonreview.net/ blog/nick-admussen-disassembling-handgun-chinese-poetry-ouyang (accessed 15.02.2016).
} 
the Mafia put on white gloves

(黑手党 heishoudang, lit. "Black Hand party," is the generic Chinese word for gangsters)

the Falangists switch to pistols

(长枪党 changqiangdang, lit. "Long Gun Party," is the Chinese name for the Falangists of Spain

or Lebanon. 长枪 changqiang "long gun” originally meant spear, hence phalanx, hence Falangists.)

(短枪 duanqiang, lit. "short gun," means handgun or pistol)

eternal Venus stands in stone

her hands rejecting humanity

from her chest she pulls a pair of drawers

inside, two bullets and a gun

pull the trigger and it becomes a toy

murder, hang fire

[Ouyang, 2012. P. 107]

Ouyang Jianghe brings this technique to the absolute in his long poem Phoenix (Fenghuang 凤 凰, 2012), where the tension between word and image creates a special combination of the wordimage or the image-word, a parallel for which can be found in the tradition with its calligraphic dimension of the poetic text [Ouyang, 2015]. It is noteworthy that Ouyang himself is not only a poet, but also a practicing calligrapher, and his poem was written as a tribute to the sculptor Xu Bing 徐 冰 (b. 1955) ${ }^{8}$, who created a grandiose installation with the same name.

$\mathrm{Xu}$ Bing is interesting not only as the author of the stimulus to compose Ouyang's Phoenix, but also as an experimental artist, who works with poetic texts, too. In his artworks, he exploits one of the strategies of performative poetry, turning the text into a background, a texture, and thereby creating a tension between the foreground and background, leading the text to 'disappear'. For the Book from the Sky project (Tian shu 天书, 1987-1991) he created a huge mass of texts printed on paper and presented in the form of books and calligraphic scrolls; none of the 4000 characters involved exist in the Chinese script - they have all been created by Xu Bing himself ${ }^{9}$ (Fig. 1, 1).

Another of his experiments related to recording of western poetic classics (for example, The Song of Wandering Aengus by W. B. Yeats) with signs imitating Chinese writing but representing a cunningly arranged stylization of the Latin alphabet. The experiment was called 'Square Word Calligraphy, ${ }^{10}$ (Fig. 1, 2).

The material character of the text is projected into its semantics. It creates an effect of a semanticized form. The word does not have to be in a relationship of direct collision with visual units, so that it is clear that the sign system, which we call language, is under some kind of attack (under the influence of intervention), but the method of turning the text into a wallpaper, a texture, a façade generates a dissolution of the text. It becomes perceived through the body - its relationship with space, with singularity is now differently related to the human body (with a greater feeling of the form).

\footnotetext{
${ }^{8} \mathrm{Xu}$ Bing is a renowned artist, author of stunning installations, the inventor of a new type of calligraphy based on Chinese characters. He began his professional career in the PRC, then lived for about 18 years in the United States, and is currently the vice president of the Beijing Academy of Arts.

${ }^{9} \mathrm{Xu}$ Bing. Tian shu [天书] Book from the Sky // Xu Bing Studio, 2009. URL: http://www.xubing.com/index. php/site/projects/year/1987/book_from_the_sky (accessed 15.02.2016).

${ }^{10} \mathrm{Xu}$ Bing. Yingwen fangkuaizi shufa rumen [英文方块字书法入门] Square Calligraphy Classroom // Xu Bing Studio, 2009. URL: http://www.xubing.com/index.php/site/projects/year/1994/square_calligraphy_classroom (accessed 15.02.2016).
} 

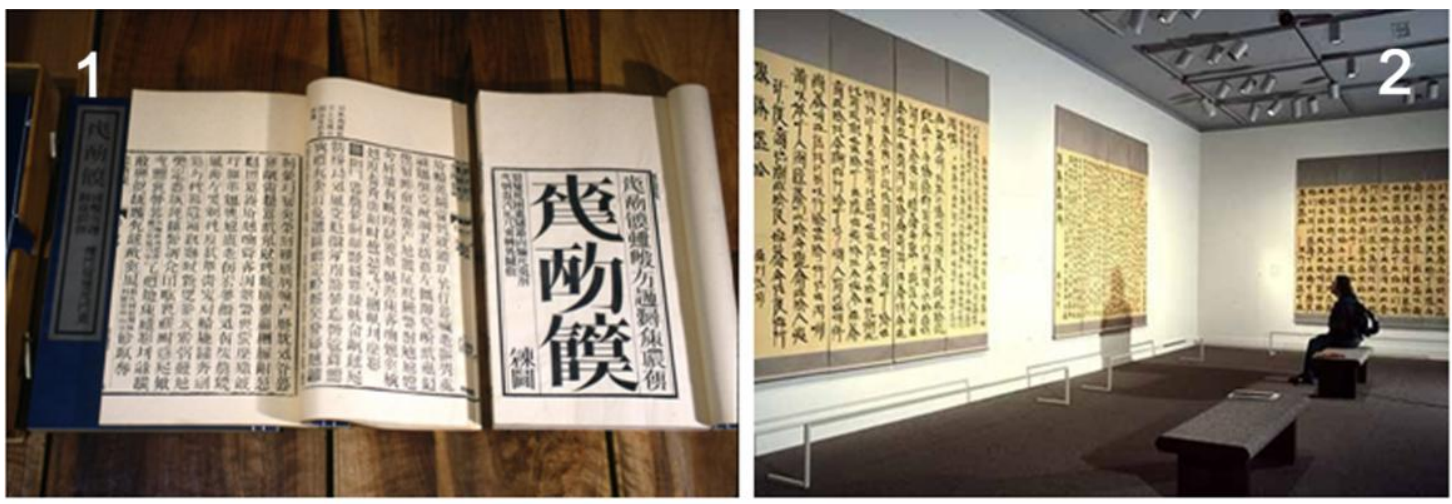

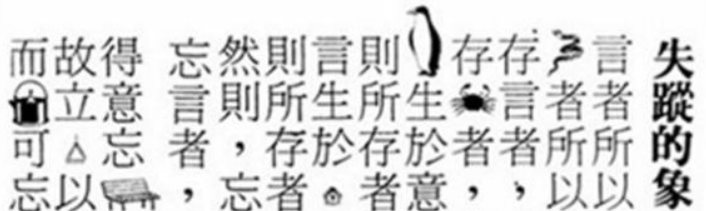

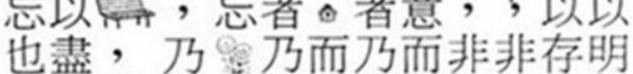

意得 得者非存非存得得意物

$\exists$ 其言其一意心ow，

忘 者乃言焉 焉者者得得
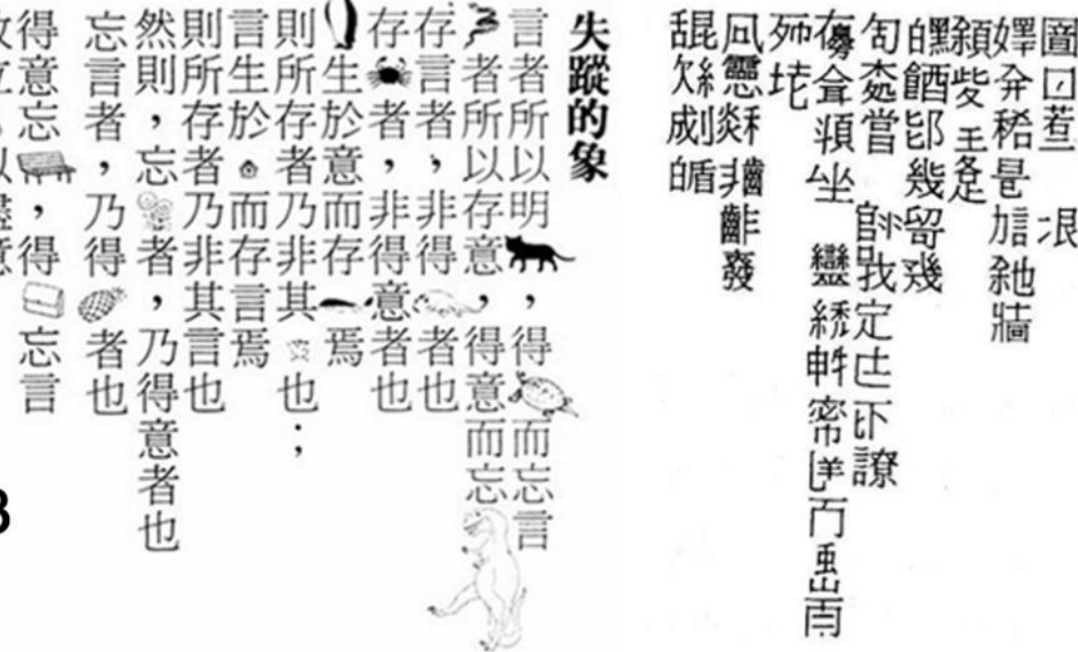

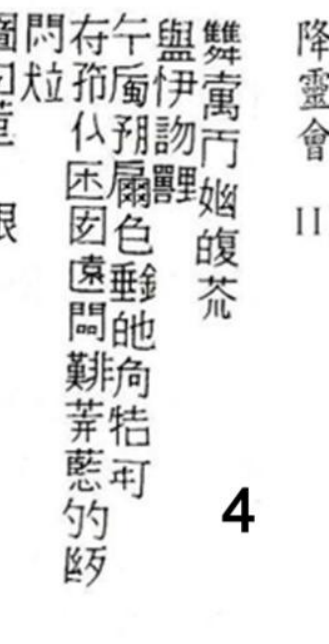

Fig. 1. Performative Strategies in Contemporary Chinese Avant-garde Poetry:

1 - Xu Bing, «Book from the Sky», 1987-1991. 100 boxed sets of 4-volume woodblock printed books. Image courtesy of Xu Bing Studio; 2 - Installation view of the exhibition 'Word Play: Contemporary Art by Xu Bing' at Arthur M. Sackler Gallery, Washington D.C., 2001. Image courtesy of Xu Bing Studio; 3 - Hsia Yü, «Lost Image». Image courtesy of Hsia Yü; 4 - Hsia Yü, «Spiritism Session III». Image courtesy of Hsia Yü

Puc. 1. Перформативные стратегии в современной китайской авангардной поэзии:

1 - Сюй Бин, «Небесная книга», 1987-1991. 100 коробочных наборов 4-томных печатных книг. Изображение предоставлено Xu Bing Studio; 2 - Инсталляционный вид выставки «Игра слов: современное искусство Сюй Бина» в галерее Артура М. Саклера, Вашингтон, округ Колумбия, 2001. Изображение предоставлено Хu Bing Studio; 3 Ся Юй, стихотворение «Утерянный символ». Изображение предоставлено Ся Юй; 4 - Ся Юй, стихотворение «Спиритический сеанс III». Изображение предоставлено Ся Юй

\section{Intervention: Nontransparency and Spaciality}

The works of Xu Bing can be considered the ultimate case of the implementation of intervention strategy when the very spatial organization of the text becomes an intervention in the field of its logic. This affects such an important criterion as the text's readability - in normal, neutral perception this moment is neutralized, and we perceive the text as transparent. A counter example is the experimental text of the Taiwanese poet Hsia Yü 夏宇 (b. 1956) ${ }^{11}$ : her first collection Memoran-

\footnotetext{
${ }^{11}$ Xia Yu (also Hsia Yü, pen name of Huang Qingqi 黄慶綺) is a Taiwanese postmodern poet, author of essays, dramas, stories, one of the loudest voices in Taiwanese feminist poetry.
} 
dum (Beiwanglu 備忘錄, 1984) was created, bypassing the commercial channels of publication, in the form of a poetic book of atypical form and size written in half-childish handwriting with illustrations resembling frames from cartoons. A typical example is the poem Lost Image (Shizong de xiang 失蹤的象), where all occurrences of the word 'image' are replaced by illustrations [Xia, 2001. P. 54-55] (Fig. 1, 3).

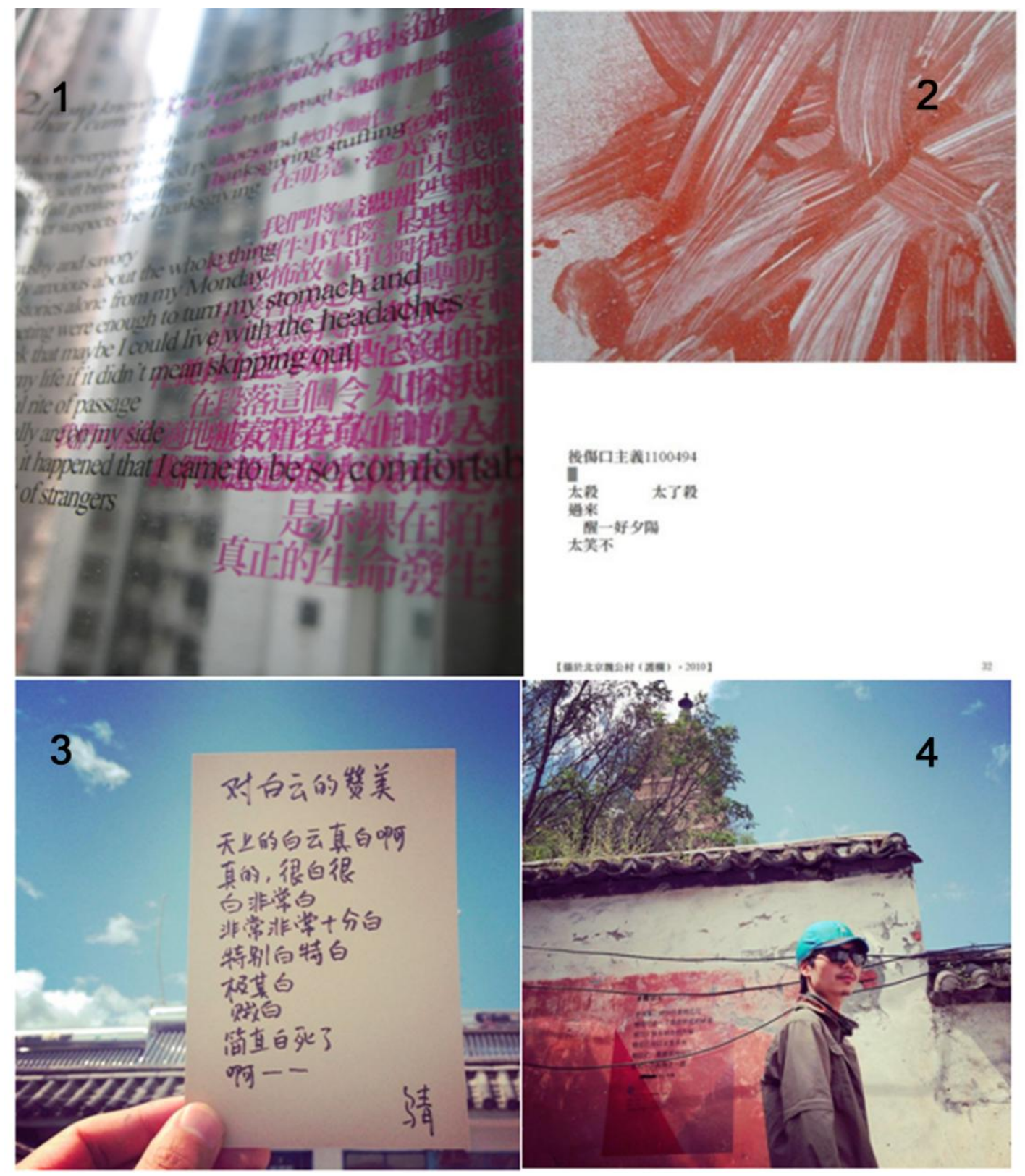

Fig. 2. Performative Strategies in Contemporary Chinese Avant-garde Poetry:

1 - Hsia Yü, Pink Noise cover; 2 - Yang Xiaobin, page 32 from Trace and Palimpsest. Image courtesy Yang Xiaobin; 3 Wuqing, «Praise for the White Clouds». Image courtesy Wuqing; 4 - PoemHere project. Image courtesy of Wuqing

Puc. 2. Перформативные стратегии в современной китайской авангардной поэзии:

1 - Ся Юй, обложка книги «Розовый шум»; 2 - Ян Сяобинь, стр. 32 из книги «След и палимпсест». Изображение предоставлено Ян Сяобинем; 3 - Уцин, стихотворение «Хвала белым облакам». Изображение предоставлено Уцином; 4 - Проект «Стихотворение-здесь». Изображение предоставлено Уцином 
This determined the model of all her subsequent books - Ventriloquism (Fuyushu 腹語術, 1990), Rub/ Indescribable (Moca・Wu yi mingzhuang 摩擦・無以名狀, 1995), Salsa (1999) and Pink Noise (Fenhongse zaoyin 粉紅色噪音, 2007).

Experiments with language as presented in Memorandum begin to play an increasingly important role in the poetry of Xia Yü. She creates pseudo-characters in the spirit of the avant-garde antiwriting in the poem Spiritism Session III (Jiangling hui 降霝會 III, 1990) [Xia 2001. P. 45], while the book Rub/ Indescribable consists entirely of collages with fragments cut from the poems of the collection Ventriloquism (Fig. 1, 4).

Pink Noise contains thirty-three poems on a transparent film; each poem explores the topic of transparency of meaning and is presented in English (in one case in French) and in Chinese translation, and the Chinese text is coloured in bright pink (Fig. 2, 1).

Using transparent sheets of paper makes you think about the corporeality of the text and sets up non-standard relations with its material carrier. This is the moment neutralized in the usually printed text, however, within the framework of the experiment, its 'thingism' turns out to be incorporated into the semantics (the idea of text as a thing).

English poems of Pink Noise are text collages, while their Chinese translations were performed using the machine translation software Sherlock, as a result, they abound with translation errors and strangely worded Chinese phrases. Due to the use of an extreme degree of estrangement, the line between 'original' and 'translation', between 'the language of the original' and 'target language', is blurred, expanding in the process the signifying horizon of Chinese.

Similar experiments characterize the work of the Australian-Chinese poet Ouyang $\mathrm{Yu}$ 欧阳昱 (b. 1955) ${ }^{12}$, who often uses a mixture of two languages within the space of one poem, down to their confusion within one language unit (as in the poem $\mathrm{Di}$ 皮 lation, 2010). His latest poetry collection boldly entitled Self Translation (2012) ends with three poems, organized quite nontrivially in terms of the visual, which combine two languages - Chinese and English. In 隻/Double, he consistently translates each line of the poem - playing with the idea of alternation, including alternating black and white space on the page. This actualizes an important moment of the practice of performative poetry, i.e. the spatial dimension of the text, emphasizing lability - linear, material and physiological:

隻/Double

Beautiful morning

美麗的清晨

A bird walks up to me

一頭鳥朝我走來

Like a chook

像只雞

Black across the breast

胸脯全黑

Right up to the hip

一直黑到屁股

I thought he might attack me

我以為牠會向我發起攻擊

\footnotetext{
${ }^{12}$ Ouyang Yu is a native of southern China (Hubei province), a specialist in American and Australian literature. Since 1991 he has lived in Australia.
} 
With his heel-like beak

用牠像高跟的鳥豚

But he walks away

但地走開了

And shits

拉了一泡单

Before he takes flight

然後飛走

Leaving a pool of snow white

留下一灘雪白的束西

[Ouyang, 2012. P. 235]

The last poem of Ouyang Yu's collection, Two Roads, returns the reader to the bilingual format of presentation, but now both pages of the turn include Chinese and English, which alternate not only line by line, but also within a single line. Two paired pieces present a reflection on the theme of The Road Not Taken by Robert Frost, they are designed to provoke a monolingual reader to take both roads (poems), reading Chinese or English words, jumping from the left to the right page and back. The last stanza in both cases is written in two languages, but the word 'taken' is removed from the English text and replaced with a Chinese translation and appears in the Chinese text on the left. The poem ends with an extra line in English in the left, mostly Chinese, stanza: 'There's nothing you can't do that you do'. On the opposite page, the stanza ends with the phrase 'You have no choice, you have many choices'. To the left, it corresponds to an empty space - the potency of the translation that has not yet been realized.

\section{兩條路}

我的面前沒有那座林子

外面，黑夜越來越深

早已錯過了約會的時間

秋天，也許不久就回到來

The roads may have diverged in

You can, though, travel in both

If only physically on one

While metaphysically on the other

一個人活久了就不是一個人

時光逐漸在肉中堆積

回頭路是沒有的

往前走的路也有盡頭

Two roads are two feet

That go way and come back

Who is there to say that future is not

The past and the time does not

\section{Two Roads}

The wood is not in front of me

Outside, the night deepens

I have long missed the hour of appointment

The autumn, it may soon arrive

路也許在林中分叉

但您能同時走雨條

一條用腳

一條用腦

One is no one when he lives too long

Time accumulates in the flesh

There's no road back

Although the road forward does come to an

end
雨條路就是雨隻腳

去去也就回了

誰能說將來不是

過去，時光永遠就不永駐？ 
沒有 taken 的路其實已經 taken

已經 taken 過的，不一定是必經之路

你別無選擇，你選擇很多

There's nothing you can't do that

[Ouyang, 2012. P. 238-239]
The road not 走 has actually been 走了

The one 走了的, not necessarily the one

one wants to take

You have no choice, you have many choices

you do

Contemporary Chinese poetry demonstrates a tendency towards converging word and image. Many authors use this convergence of visual and verbal as a means of renewing their poetics. It reflects not only an orientation towards a creative dialogue with the art of previous periods, but also the emergence of new expressive means that implicate language experiments (including words as asemantic images).

Examples of this approach include formal experiments of poet-cum-artist Yan $\mathrm{Li}$ 严力 (b. 1954) ${ }^{13}$, calligraphic explorations of Ouyang Jianghe, and works of several poetry groups and circles, among others - the 'Marvelous Enlightenment' calligraphy school (miao wu 妙悟) ${ }^{14}$. This use of hybrid formats for information presentation captures new ways of visual-verbal interaction in rethinking of the literati tradition. At the same time, it constitutes a part of our need for surviving in a global text field, where misunderstanding of the text language in constant crossing of linguistic borders is increasingly becoming an important part of our practice.

In Chinese visual poetry, the most vivid examples of working with textual space are presented in the works of the Taiwanese poet Chen Li 陳黎 (b. 1954) ${ }^{15}$ and, in particular, his famous War Symphony (Zhanzheng jiaoxiangqu 战争交响曲, 1995). In the works of Chen $\mathrm{Li}$, the language itself becomes the aim and the object of the poem, representing itself.

兵兵兵兵兵兵兵兵兵兵兵兵兵兵兵兵兵兵兵兵兵 兵兵兵兵兵兵兵兵兵兵兵兵兵兵兵兵兵兵兵兵兵兵兵 兵兵兵兵兵兵兵兵兵兵兵兵兵兵兵兵兵兵兵兵兵兵兵 兵兵兵兵兵兵兵兵兵兵兵兵兵兵兵兵兵兵兵兵兵兵兵 兵兵兵兵兵兵兵兵兵兵兵兵兵兵兵兵兵兵兵兵兵兵兵 兵兵兵兵兵兵兵兵兵兵兵兵兵兵兵兵兵兵兵兵兵 兵兵兵兵兵兵兵兵兵兵兵兵兵兵兵兵兵兵兵兵兵兵 兵兵兵兵兵兵兵兵兵兵兵兵兵兵兵兵兵兵兵兵兵兵兵 兵兵兵兵兵兵兵兵兵兵兵兵兵兵兵兵兵兵兵兵兵兵

${ }^{13}$ Yan Li works both in poetry and in visual arts. He began his career in the 1980s: in 1985 his first solo exhibition took place in Shanghai (the same year he moved to New York). Solo exhibitions of Yan Li's work have been organized at Feng Gallery, Vassar College, Art Waves Gallery. In 1987, he launched his own literary magazine, One Line (Yi hang 行), bringing together many experimental authors both in China and abroad. Seven years later, Yan returned to China and settled in Shanghai, in 2012 he opened an art studio in Beijing.

${ }^{14}$ The use of hybrid formats for presenting information fixes new ways of visual-verbal interaction in the practice of rethinking the traditional literati tradition. Various organizations of poets engaged in visual art undertake such type of explorations. One of the most significant associations of this kind is the miao wu school, one of the main figures in which is the Taiwanese poet Luo Qing 罗青 (b. 1948). The list of participants is constantly changing, but there are authors who constantly participate in the activities of the association: Li Zhan'gang 李占刚 (b. 1963), Chen Zhongcun 陈忠村 (b. 1975), Qi Guo 新国 (b. 1968), etc.

The school's manifesto, authored by Luo Qing, describes an aesthetic strategy reminiscent of the surrealists. It serves the purpose of combining the modernist expression of the Euro-American avant-garde of the first half of the 20th century and the Chinese tradition of visual arts. The works of the representatives of the school are very different, but they are united by an orientation towards the dialogue of the verbal and visual, adapting poetic texts from both sides of the strait.

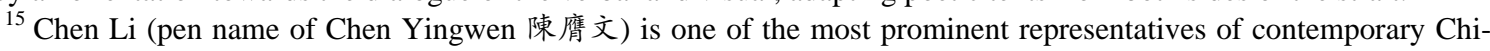
nese poetry from Taiwan. He is a winner of many significant poetry awards and has published more than ten collections of poetry and translations. 
兵兵兵兵兵兵兵兵兵兵兵兵兵兵兵兵兵兵兵兵兵兵 兵兵兵兵兵兵兵兵兵兵兵兵兵兵兵兵兵兵兵兵兵 兵兵兵兵兵兵兵兵兵兵兵兵兵兵兵兵兵兵兵兵兵兵兵兵 兵兵兵兵兵兵兵兵兵兵兵兵兵兵兵兵兵兵兵兵兵兵兵兵 兵兵兵兵兵兵兵兵兵兵兵兵兵兵兵兵兵兵兵兵兵兵兵兵 兵兵兵兵兵兵兵兵兵兵兵兵兵兵兵兵兵兵兵兵兵兵兵 兵兵兵兵兵兵兵兵兵兵兵兵兵兵兵兵兵兵兵兵

兵兵兵兵兵兵兵兵兵兵兵兵兵兵兵兵兵兵兵兵兵兵 兵兵兵兵兵兵兵兵兵兵兵兵兵兵兵兵兵兵兵兵 兵兵兵兵兵兵兵兵兵兵兵兵兵兵兵兵兵兵兵 兵兵兵兵兵兵兵兵兵兵兵兵兵兵兵兵兵兵兵 兵兵兵兵兵兵兵兵兵兵兵兵兵兵兵兵兵兵兵 兵兵兵兵兵兵兵兵兵兵兵兵兵兵兵兵兵兵 兵兵兵兵兵兵兵兵兵兵兵兵兵兵兵兵兵兵 兵兵兵兵兵兵兵兵兵兵兵兵兵兵兵兵兵兵兵 兵兵兵兵兵兵兵兵兵兵兵兵兵兵兵兵兵兵 兵兵兵兵兵兵兵兵兵兵兵兵兵 兵兵兵 兵兵兵兵兵兵兵兵兵兵兵兵 兵兵兵兵兵兵兵兵兵兵

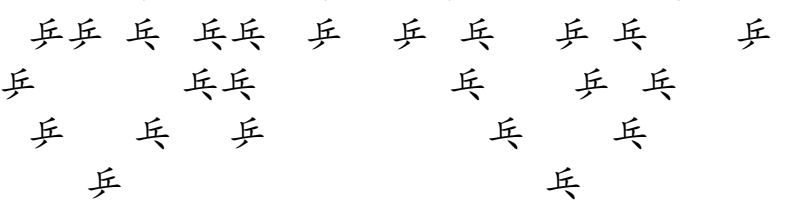

丘丘丘丘丘丘丘丘丘丘丘丘丘丘丘丘丘丘

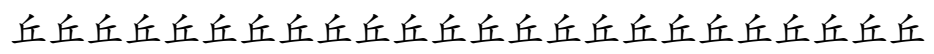

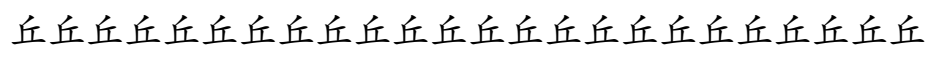

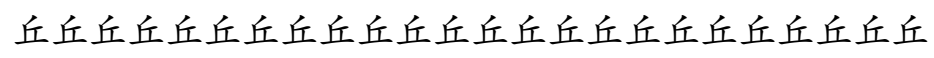

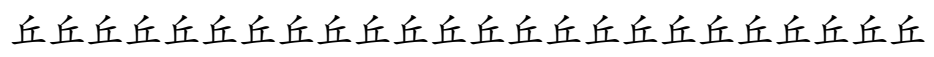

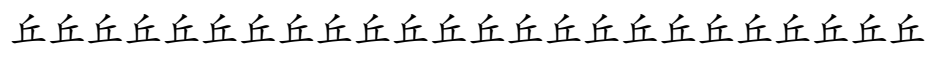

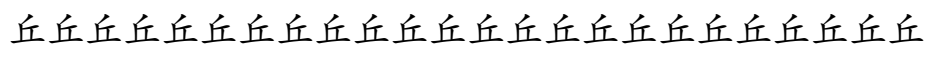

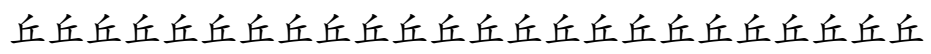

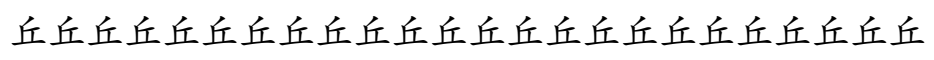

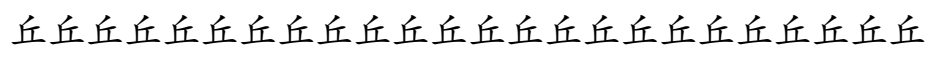

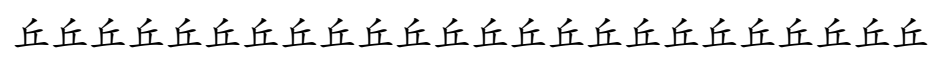

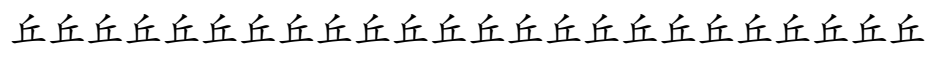

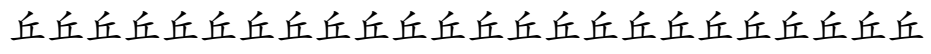

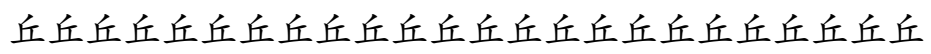

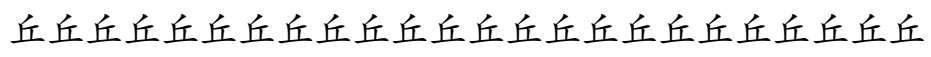
丘丘丘丘丘丘丘丘丘丘丘丘丘丘丘丘丘

[Language for a New Century, 2008. P. 376]

In accordance with the typical structure of a musical symphony, the work breaks down into three fragments of the same size. The first consists of 384 characters 兵 bing ('soldier'), arranged in the form of 16 lines with 24 characters each. They constitute a perfectly organized rectangle that evokes 
the image of a military parade. The second fragment introduces a certain irregularity: with the appearance of the characters 兵 ping and pang 兵 the whole structure crumbles, spaces appear, as they move downwards, they become larger. Ping and pang, differing from bing only by the absence of one of the bottom lines, write down onomatopoetic words hinting at the clapping of shots. At the same time, they look like images of soldiers with lost limbs. The last fragment restores the former orderliness: all the bing characters are replaced with 丘 qiu ('hill') - the soldiers end up in the grave ${ }^{16}$

This poem is remarkable for its ingenious use of graphics, but also the phonetics of Chinese language in their connection with each other. All three syllables bing, ping and pang are closed syllables and begin with stop consonants, while qiu begins with an affricate. This syllable is an open one, with an extended time of pronouncing. The presentation of the poem conducted by Chen Li himself additionally emphasizes the duration and aspiration of $q i u$, imitating the whistling of the wind. Thus, the last fragment of the Military Symphony not only visually represents a number of graves, but also complements this picture with the wind blowing over them. Qiu also has a homonym meaning 'autumn' - a concept traditionally associated in Chinese culture with the idea of the frailty of all existence and fanned by an atmosphere of sadness.

Chen Li's poem is not only a piece of evidence of how concrete poetry concentrates entirely on the language itself, it also illustrates the common concern of the contemporary Chinese poet with the problem of poetic language, his immersion in the discourse about poetic function understood in the spirit of Roman Jacobson [Jacobson, 1997]. Language is no longer a means of describing or transmitting facts, thoughts, and emotions; it becomes the goal and object of a poem, representing itself. Contemporary Chinese experimental poetry uses visual and acoustic aspects of speech as an object of poeticization; the signs of language are isolated from their conventional usage to lead the reader and listener to other semiotic dimensions.

Operating with characters, which are external to the language, also constitutes one of the strategies of performative verse, which explores the possibilities of double or even triple coding. The meaning of nonsingular coding is that other types of coding (visual, physical, spatial) are superimposed on language coding. This can be seen, for example, in the works of Yang Xiaobin 杨小滨 (b. 1963) ${ }^{17}$ from the series Trace and Palimpsest (Zongji yu tumo 蹤跡與塗抹, 2005-2012), that combine the visual and the textual (Fig. 2,2).

We also see it in Wuqing 乌青 (b. 1978) ${ }^{18}$ in his project PoemHere (Zheli you shi 这里有诗, http://poemhere.org/), where the poetic text of a Web author 'devirtualizes' and begins to interact with the real space (Fig. 2, 3,4).

\section{Self-Actualization: The Esoteric Dimension}

For performative poetry, not only the spatial but also the 'esoteric' dimension of the text is quite significant, i.e. the phenomenon of self-actualization of the text - at the level of a semanticized form. It is observed in many poets, for example, in Yang Lian 杨炼 (b. 1955) ${ }^{19}$. His long cycle Concen-

\footnotetext{
${ }^{16}$ One might even say that the Symphony is a bold and impressive experiment with the Chinese written sign that is only loosely tied with the 'word' idea of the European tradition: the range of its visual effects is evidenced by the variability of its associations - not only with a military parade, but also with the alignment of ceramic warrior figures from ancient burials, which also correlates with the qiu character (many thanks to the honored reviewer of this paper for pointing out this to the author).

${ }^{17}$ Yang Xiaobin is a poet, critic, and photo artist. He was born in Shanghai, and received his doctorate from Yale University. Yang is a researcher at the Institute of Chinese Literature and Philosophy of the Academy of Sciences (Academia Sinica), lecturer at Chengchi State University, editor-in-chief of Poetry on Both Sides of the Straits magazine, jury member and secretary of the Beijing International Poetry Award. He has been living in Taiwan since 2006.

${ }^{18}$ Wuqing (pen name of Zheng Gongyu 郑功宇) is a native of southeastern China (Zhejiang province) and a wellknown known Internet poet - seven of his collections have been published on the Web.

${ }^{19}$ Yang Lian was born in Bern, Switzerland, but lived in Beijing since childhood. In 1989 he left for New Zealand. For supporting student demonstrations in Tian'anmen he was stripped of Chinese citizenship, and soon got naturalized in
} 
tric Circles (Tongxinyuan 同心圆, 1994-1997) includes the poem Who (Shei 谁), where the words are devoid of any meaning, but the metric pattern of the work exactly corresponds to the traditional metric scheme of the cipai 词牌Waves Washing Sands (Lang tao sha 浪淘沙):

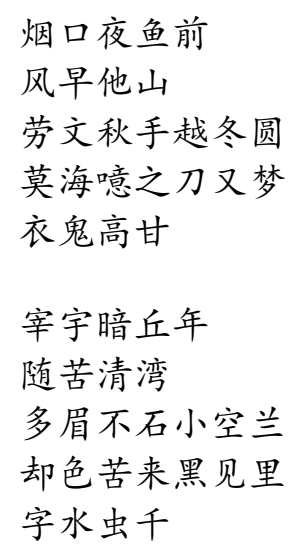

The word-for-word translation of the above-mentioned fragment looks like this:

smoke mouth in front night found

mountains he morning grand

labour text hand autumn round

ocean knife dream never sand

clothes ghost sweet tall sound

all slaughter year dark mound

bitter after blue-green band

not stone brow stand small ground

beauty come bitter black brand

word water bug million resound

The English translation by Brian Holton presents an attempt to invoke the sound of the Chinese by substituting English words as close as possible to the sound of the Chinese. As Holton notes, Yang Lian suggested producing a text, which made no sense, yet had a structure, which was clearly visible in English ${ }^{20}$. After much experiment, he found the Welsh bardic metre Cyhydedd Hir, which is composed of an octave stanza of two quatrains with a strict rhyme-scheme. The title had to change from the original Who, which is the sense of the Chinese, to something closer to shui, the sound of the original:

\section{SWAY}

yank so yeah you chin fen sought bam show shin choose ewe add fling sin moat high ease door fin eik wall gun gog

New Zealand. Yang used to live in London and Berlin, and currently lectures at Swatow University, Guangdong. In 19992003 three of his collections were published in the PRC. He is a poet, essayist, literary critic, and is actively involved in international teaching activities (Australia, New Zealand, USA, France, Germany, Great Britain).

${ }^{20}$ Holton B. Driving to the Harbour of Heaven: Translating Yang Lian's Concentric Circles // Cipher Journal. 2005. URL: http://www.cipherjournal.com/html/holton.html (retrieved 26.11.2018). 
sigh you anti dan squeak couching ban doe hay bushy shan coolie herring fan fizz way chaw cog [Yang, 2006. P. 78]

The effect to which the poet aspires is similar to the impression of an abstract painting, with the word as its material. In the poem Lie (Huang 谎) of the same cycle, there is an entire line composed of more than twenty determinatives - graphic elements that do possess their own names but lack any phonetic correspondence and meaning, except for their function of thematic classifiers:

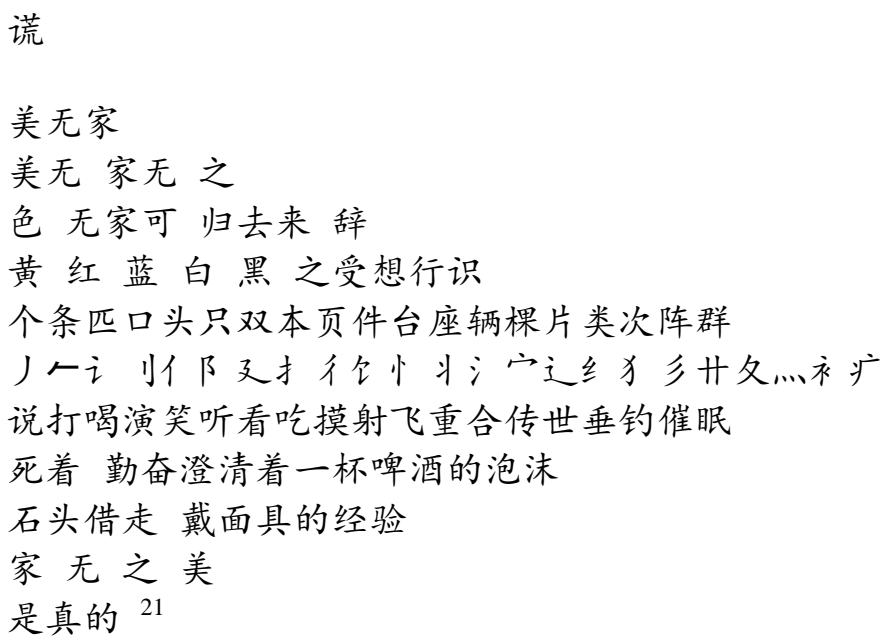

Holton's ingenious translation that substitutes determinatives for English suffixes and prefixes reads like this:

\section{LIES}

beauty sans home

beauty sans home sans its

colour sans home may Homeward Ho! say

yellow red blue white black their rūpa vedanā samjña samskāra vijñāra

score pound foot shoal pint flock sheet leaf brace volume gaggle fathom dram

super al con ician mono ante ism per inity alysis cata intra ana ness pro ation ery

say hit drink play smile eat touch shoot fly co-in-cide pisc-itate hypno-tise

dying attending to clarifying the foam on a glass of beer

stone borrows masked experience

home sans its beauty

is true

[Yang, 2006. P. 80]

\section{Conclusion}

The use of language shift principles shows how performative strategies adapt in the framework of contemporary Chinese poetry, linking radically new with deeply traditional - as it happens, for

\footnotetext{
${ }^{21}$ Yang Lian. Shi liang shou [诗两首] Two Poems // Poetopia, 2014. No. 3. URL: http://shige.artsbj.com/stb_003/ (accessed 22.11.2018) (in Chinese).
} 
example, in the case of operating with the calligraphic dimension of the text. The concentrated nature of Chinese script provides opportunities to work with what Charles Olson called the 'composition by field' - movement across the entire surface of the page ${ }^{22}$. In poetry, with Chinese characters as its medium, the possibility of close interaction and even the joint reading of words that are adjacent vertically existed even at the stage of classical verse, before the advent of the avant-garde. Graphic design is complemented by the alignment of the nominative series, the arrangement of words next to each other in an associative rather than a syntactic connection.

Contemporary Chinese poetry demonstrates a tendency towards converging word and image. Many authors use this convergence of visual and verbal as a means of renewing their poetics. It reflects an orientation towards a creative dialogue with the art of the past, but also an emergence of new expressive means that implicate language experiment. This use of hybrid formats for information presentation captures new ways of visual-verbal interaction in rethinking of the literati tradition. At the same time, it constitutes a part of our need for surviving in a global text field, where misunderstanding of the text language in constant crossing of linguistic borders is increasingly becoming an important part of our practice.

What we see here are the hidden esoteric dimensions of the text - not esoteric in the sense of spiritual practices, but in the sense of its self-realization. We are accustomed to perceive the text in avant-garde poetry as a kind of complication when compared to the 'usual' text of the quotidian, but it is also possible to (re)construct it as an eidetic reduction, as a kind of semantic cleansing. This presence of absence creates a vibrating sign, an image that is a way of speaking, albeit not in words, but in images (here again colliding with Boehm's idea of the 'iconic turn'). In Chinese, it is brought to life by exploring the mediality potential of the character.

Working with signs that are alien in relation to language raises the question of the transferability of sign, which has two vectors: an optimistic one (universality of semiotic systems) and a pessimistic one (each part of the sign is untranslatable in its singularity). Thus, the language comes out of the margins of its expressive means trying to express some types of meaning. This creates a hierarchy of text zones, a writing architecture presenting the text as a palimpsest (the title of Yang Xiaobin's visual series Trace and Palimpsest is rather symptomatic in this respect).

Provocations / subversions of text reception and production are implemented through several techniques: texturizing, spacialization, opacity (nontransparency), and sign creation. The internal structure of the image, its connection with the material carrier and the potential of the image as a resource of knowledge - all is reflected both in the performative strategies of avant-garde art and in their 'localization' in the mainstream of the Chinese tradition, based on the special properties of its written signs. Both authors from Greater China and emigrants who have long been immersed in Western culture, people with different backgrounds, interests, political views, and the ability to orient in the Western aesthetic universe, form an artistic community that makes it possible to identify the features universal for the experimental word art as practiced by avant-garde poets writing in Chinese. The main universal is the actualization of the basic properties of Chinese character and the performative methods, which have been functioning since ancient times in the realm of Chinese culture.

\section{References}

Boehm G., Mitchell W. J. T. Pictorial versus Iconic Turn: Two Letters. Culture, Theory and Critique, 2009, vol. 50, p. 103-121.

Bukovsky V. To Build a Castle: My Life as a Dissenter. New York, 1979, 438 p.

Chernyavskaya V. E. Mediality: analyzing a new paradigm in linguistics. Media Linguistics, 2015, no. 1 (6), p. 7-14. (in Russ.)

Day M. China's Second World of Poetry: The Sichuan Avant-Garde, 1982-1992. Leiden, 2005, $570 \mathrm{p}$.

${ }^{22}$ Olson C. Projective Verse // Poetry Foundation. 13 October 2009. URL: https://www.poetryfoundation.org/ articles/69406/projective-verse (accessed 28.05.2018). 
Grauz T. WORD. LETTER. IMAGE. On the Visual in Poetry. In: Parallel Processes in the Language of Modern and Contemporary Russian and Chinese Poetry. Ed. Y. Dreyzis. Moscow, 2019, p. 38-105.

Inwood H. Verse Going Viral: China's New Media Scenes. Seattle and London, 2014, 266 p.

Jacobson R. Linguistics and Poetics. In: Twentieth-Century Literary Theory. Ed. K. M. Newton. N. Y., 1997, p. 71-77.

Language for a New Century: Contemporary Poetry from the Middle East, Asia, and Beyond. Ed. T. Chang, N. Handal, R. Shankar. N. Y., 2008, 734 p.

Li Dian. Naming and Antinaming: Poetic Debate in Contemporary China. In: New Perspectives on Contemporary Chinese Poetry. Ed. C. Lupke. New York, 2008. p. 185-201.

Manfredi P. Modern Poetry in China: A Visual-Verbal Dynamic. Amherst: Cambria Press, 2014, $244 \mathrm{p}$.

Nöth W. The (meta-)textual space. In: The Construal of Space in Language and Thought. Ed. M. Pütz, R. Dirven. Berlin, 1996, p. 599-612.

Ouyang Jianghe. Doubled Shadows: Selected Poetry of Ouyang Jianghe. Trans. A. Woerner. Brookline, MA, 2012, 137 p.

Ouyang Jianghe. Phoenix. Trans. A. Woerner. Brookline, MA, 2015, 64 p.

Ouyang Yu. Self Translation. Yarraville, 2012, 242 p.

Šuvaković M. Impossible Histories. In: Impossible Histories: Historical Avant-gardes, Neo-avantgardes, and Post-avant-gardes in Yugoslavia, 1918-1991. Ed. D. Djurić, M. Šuvaković. Cambridge, 2003, p. 2-36.

Crevel M. van. Language Shattered: Contemporary Chinese Poetry and Duoduo. Leiden, 1996, $355 \mathrm{p}$.

Crevel M. van. Chinese Poetry in Times of Mind, Mayhem and Money. Leiden, 2008, 518 p.

Xia Yu. Fuyushu [腹語術]. Ventriloquism. Taipei, 2001, 123 p. (in Chin.).

Yang Lian. Concentric circles. Trans. B. Holton, A. Hung-Chong Chan. Hexham, Northumberland, $2006,128 \mathrm{p}$.

Yang Xiaobin. Zongji yu tumo: Housheyingzhuyi [蹤跡與塗抹: 後攝影主義] Trace and Palimpsest: Postphotographism. Taipei, 2012, 47 p. (in Chin.).

Yeh M. Modern Chinese Poetry: Theory and Practice since 1917. New Haven, 1991, 252 p.

Материал поступил в редколлегию

Received

25.08.2020

\section{Сведения об авторе}

Дрейзис Юлия Александровна, кандидат филологических наук, доцент кафедры китайской филологии Института стран Азии и Африки Московского государственного университета им. М. В. Ломоносова; научный сотрудник сектора теоретического языкознания Института языкознания РАН (Москва, Россия)

yulia.dreyzis@gmail.com

\section{Information about the Author}

Yulia A. Dreyzis, Candidate of Science (Philology), Associate Professor, Chinese Philology Department, Institute of Asian and African Studies, Moscow State University; Research Fellow, Sector of Theoretical Linguistics, Institute of Linguistics, Russian Academy of Sciences (Moscow, Russian Federation)

yulia.dreyzis@gmail.com 